\title{
Compressive strength behaviour of low- and medium-strength concrete specimens confined with carbon fibres in defective implementation conditions: an experimental study
}

\author{
M. Fernández-Cánovas, M.N. González-García $\bowtie$, J.Á. Piñero, A. Cobo \\ Escuela Técnica Superior de Edificación de Madrid, Technical University of Madrid (Madrid, España)
}

\mariadelasnieves.gonzalez@upm.es

Received 24 September 2015

Accepted 20 April 2016

Available on line 4 October 2016

\begin{abstract}
This behaviour of low- and medium-strength concrete specimens confined with carbon fibrereinforced polymer (CFRP) was analysed in three loading cycles. In some cases, stress levels were achieved that produced intemal microcracks, which allowed residual rigidity and the behaviour of completely microcraked concrete specimens to be studied. The specimens were subsequently tested to compression to the fracture point. Specimens reinforced in accordance with no manufacturing defects ( $100 \%$ CFRP reinforcement) and major manufacturing defects (50\% CFRP reinforcement) were assessed for effectiveness and behaviour of the confined elements in less than ideal conditions. Results show that confinement was higher in lowresistance concretes, that the behaviour of reinforced specimens was unaffected by defective implementation conditions and that the reinforced specimens were less rigid than the non-reinforced specimens when tested up to $40 \%$ of ultimate fracture strength.
\end{abstract}

KEYWORDS: Concrete; Composite; Compressive strength; Strain; Modulus of elasticity

Citation/Citar como: Fernández-Cánovas, M.; González-García, M.N.; Piñero, J.A.; Cobo, A. (2016) Compressive strength behaviour of low- and medium-strength concrete specimens confined with carbon fibres in defective implementation conditions: an experimental study. Mater. Construcc. 66 [324], e103. http://dx.doi. org/10.3989/mc.2016.08315

RESUMEN: Estudio experimental del comportamiento a compresión de probetas de hormigón de resistencias bajas y medias confinadas con tejidos de fibras de carbono y con defectos muy importantes de ejecución. En este trabajo se estudia el comportamiento de hormigones de resistencias bajas y medias confinados con CFRP. Se han realizado 3 ciclos de carga llegando en algunos casos a niveles de tensión que han microfisurado internamente el hormigón, lo que ha permitido estudiar la rigidez residual y el comportamiento de probetas confinadas con el hormigón totalmente microfisurado. Posteriormente todas las probetas se han ensayado a compresión hasta rotura. Los refuerzos se han realizado con buenas condiciones de ejecución y simulando grandes defectos para poder evaluar la eficacia de los elementos confinados cuando las condiciones de ejecución no son las correctas. Los resultados muestran que el efecto de confinamiento es superior en hormigones poco resistentes, el comportamiento de las probetas reforzadas es poco sensible a grandes defectos de ejecución y su rigidez es inferior al de las probetas originales cuando se ensayan hasta el $40 \%$ de la tensión de rotura.

PALABRAS CLAVE: Hormigón; Composite; Resistencia a la compresión; Deformación; Módulo elástico

Copyright: (C) 2016 CSIC. This is an open-access article distributed under the terms of the Creative Commons Attribution License (CC BY) Spain 3.0. 


\section{INTRODUCTION}

The deterioration of existing concrete structures has led to the development of new rehabilitation systems, traditionally based on steel-plate or reinforced-concrete retrofitting, which, however, have the drawbacks of being difficult to implement and costly in terms of handling and material placement (1).

Fibre-reinforced polymers (FRPs) have excellent strength/weight ratios and anti-corrosive properties and have been successfully used in the automobile, aeronautical and sports sectors $(2,3)$. They have also been usefully applied in the construction industry, as evidenced by a large number of publications (4-7) and the development of the corresponding international regulations, standards and documentation (3, 8-10).

In most FRP studies of concrete confinement, carbon, glass and aramid fibres have been used with medium-resistance concretes subject to centred compression (11-17) or eccentric loading (1, 18-19). Confinement studies of high-resistance concretes have also been published (20-23). It has been found that confinement effect is greater when concrete strength is lower (24-27) and that cyclic testing reduces rigidity (28-33). However, confinement in low-resistance concretes has not been sufficiently studied.

International standards and documentation regulating the execution and design of FRP reinforcements specify that implementation must be done with care. In many real in situ interventions, however, meticulous implementation to the level of care that is possible in laboratories cannot be guaranteed. Lacking in the literature are scientific studies of the impact of poor implementation on the behaviour of FRP-reinforced elements.

When a concrete component reaches compression stress of approximately $75 \%$ of the fracture stress, the crack system becomes unstable and internal microcracks develop in the mortar matrix (34). For values close to the $75 \%$ stress level, the available internal energy exceeds the required crack-release energy, thereby increasing the propagation rate and destabilizing the system. Due to the strength increase in confined concrete compared to the original (unconfined) concrete, it may happen that the service stress of the confined elements exceeds $75 \%$ of the ultimate strength of the unconfined concrete, resulting in a noticeable decrease in the rigidity of the elements.
Our threefold aim was to explore the behaviour of low- and medium-strength concrete specimens experimentally tested to compression and confined with carbon FRP (CFRP), as follows: (1) compare the behaviour of the two types of confined concrete; (2) study the behaviour of confined concrete when the concrete is already cracked; and (3) examine the impact of defective implementation conditions on the behaviour of reinforced specimens.

\section{METHODOLOGY}

Three types of concrete were analysed. C1 was a low-strength concrete $(8.5 \mathrm{MPa})$, analysed as an example of concrete manufactured with a high water-cement ratio. $\mathrm{C} 2$ and $\mathrm{C} 3$ were two commonly used medium-strength concretes (20.4 MPa and 25.2 $\mathrm{MPa}$, respectively). Table 1 shows the proportions of each concrete type. The cement used was CEM II/A-L type $42.5 \mathrm{R}$ manufactured by Lafarge and the maximum size of the coarse aggregate was $12 \mathrm{~mm}$

Six cylindrical specimens, diameter $150 \mathrm{~mm}$ and height $300 \mathrm{~mm}$, were prepared of each concrete type, manufactured according to EN 12390-2 (35). The 18 specimens were first cured in a humid chamber at $20^{\circ} \mathrm{C}$ and $95 \%$ humidity for 28 days and then maintained in laboratory conditions at $20^{\circ} \mathrm{C}$ and $65 \%$ humidity for seven days. Specimen surfaces were polished to ensure that the press acted on smooth and plane surfaces perpendicular to stress direction during compression testing. Two specimens of each type of concrete were not reinforced so that they could be used as benchmarks. The remaining specimens were strengthened in two distinct conditions (50\% and $100 \%$ CFRP reinforcement).

Before reinforcement, adhesive plastic sheets, some $50 \mathrm{~mm}$ wide, were glued vertically onto half of the specimens to be strengthened. These sheets were evenly distributed in such a way that $50 \%$ of the outer surface of the specimen was coated with the adhesive sheet, thereby preventing further CFRP bonding with the concrete. A primer (Drizoro XPS400) was applied to all the reinforced specimens to improve surface resistance conditions (by closing pores and surface cracks) and to increase bonding with the carbon-fibre fabric (Replark MM2 Drizoro), glued onto all the specimens after 24 hours using epoxy resin (Drizoro XL-800) (Figure 1).

A first coat of epoxy resin adhesive was applied to bond the fibre tissue to the specimens. A $10 \mathrm{~cm}$

TABLE 1. Fresh concrete content for the $\mathrm{C} 1, \mathrm{C} 2$ and $\mathrm{C} 3$ specimens

\begin{tabular}{lcccc}
\hline Concrete specimen & Cement $\left(\mathbf{K g} / \mathbf{m}^{\mathbf{3}}\right)$ & Gravel $\left(\mathbf{K g} / \mathbf{m}^{\mathbf{3}}\right)$ & Sand $\left(\mathbf{K g} / \mathbf{m}^{3}\right)$ & Water-cement ratio \\
\hline C1 & 170 & 1024 & 922 & 0.97 \\
C2 & 338 & 908 & 867 & 0.6 \\
C3 & 349 & 908 & 867 & 0.55 \\
\hline
\end{tabular}



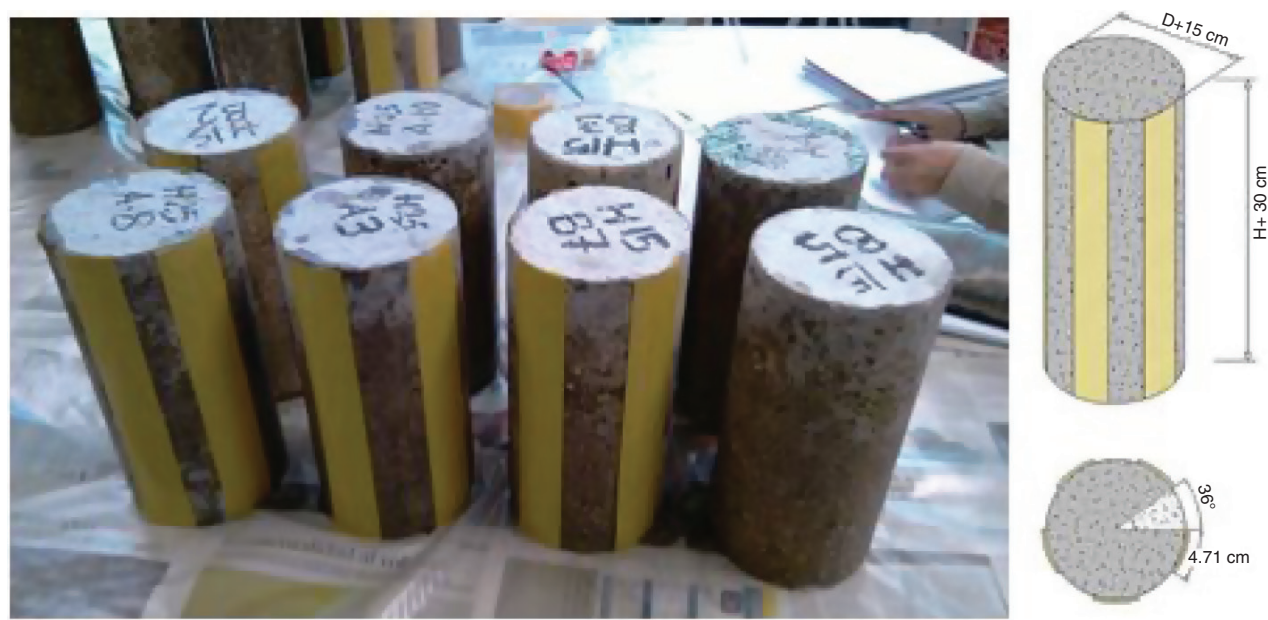

FIGURE 1. Photograph and diagram illustrating the 50\% CFRP-reinforced specimens.

TABLE 2. Mechanical properties of the composite reinforcements

\begin{tabular}{lccc}
\hline & Thickness $(\mathbf{m m})$ & Tensile strength $(\mathbf{M P a})$ & Elastic modulus $(\mathbf{M P a})$ \\
\hline Fibre tissue & 0.163 & 2400 & $4.4 \cdot 10^{5}$ \\
Resin & 0.545 & 29 & $15 \cdot 10^{3}$ \\
Composite & 0.708 & 444 & $0.81 \cdot 10^{5}$ \\
\hline
\end{tabular}

overlap was left to allow for removal of the fibre tissue when subjected to stress. Air bubbles and imperfections were subsequently removed with a roller. After 15 minutes (that is, once the coated surface was dry), a finishing coat of the same resin was applied. Two kinds of reinforced specimens were prepared: perfectly reinforced specimens $(100 \%$ of the outer surface of the test specimen bonded to the CFRP) and partially reinforced specimens (50\% of the outer surface of the test specimen bonded to the CFRP). After reinforcement, to complete the process of the resin polymerization, the specimens were left for 15 days in laboratory conditions (temperature $20^{\circ} \mathrm{C}$ and humidity $65 \%$ ). The mechanical properties of the composite reinforcements are summarized in Table 2.

All the specimens underwent three cycles of loading and unloading up to $40 \%$ of the estimated ultimate strength (Figure 2). A code of the format CXYZ was used to identify the specimens, as follows: $\mathrm{CX}$ indicates specimen type (C1, $\mathrm{C} 2$ or $\mathrm{C} 3)$; $\mathrm{Y}$ indicates test conditions (W: without reinforcement; M: 50\% fibre-reinforced surface; T: 100\% fibrereinforced surface); and $\mathrm{Z}$ - a number between 1 and 18 - identifies the individual test piece.

Specimen fracture strength without reinforcement was obtained from previous tests. The ultimate fracture for each reinforced specimen was estimated in accordance with the Lam and Teng model given by Equation [1] (36-37) as adopted by the American Concrete Institute (ACI) (3).

$$
f_{c c}=f_{c}+6.6 \psi f \frac{E_{r} n t_{f e} k_{e} \varepsilon_{f u}}{D}
$$

where

$\mathrm{f}_{\mathrm{cc}} \quad$ ultimate strength in compression of the confined concrete

$f_{c} \quad$ ultimate strength in compression of the unconfined concrete

$\mathrm{E}_{\mathrm{r}}$ elastic modulus of the reinforcing material

$\mathrm{n}$ number of reinforcing material layers

$t_{\mathrm{fe}} \quad$ thickness of the reinforcing material

D specimen diameter

$\varepsilon_{\mathrm{fu}} \quad$ ultimate strain of the reinforcing material

$\psi_{\mathrm{f}}, \mathrm{k}_{\mathrm{e}}$ coefficients.

Regarding the coefficients, $\psi_{\mathrm{f}}=0.95$ comes from ACI Committee 440 (3). $\mathrm{k}_{\mathrm{e}}$ accounts for failure of the reinforcing material to achieve ultimate strain (38) due to multiaxial stress at the location of the reinforcement material and the stress concentration caused by the concrete cracking as it dilates. Values obtained experimentally for $\mathrm{k}_{\mathrm{e}}$ range from 0.58 to $0.61(36,39-40)$. The value used in this study was the ACI (3) value of 0.55 .

Tests were conducted, controlling strain, at a speed of $10-5 \varepsilon / \mathrm{s}$, using a universal Ibertest MIB press with a load capacity of $1200 \mathrm{kN}$. Vertical displacement was recorded by means of two linear variable differential transformer (LVDT) displacement transducers. Horizontal movement was controlled 


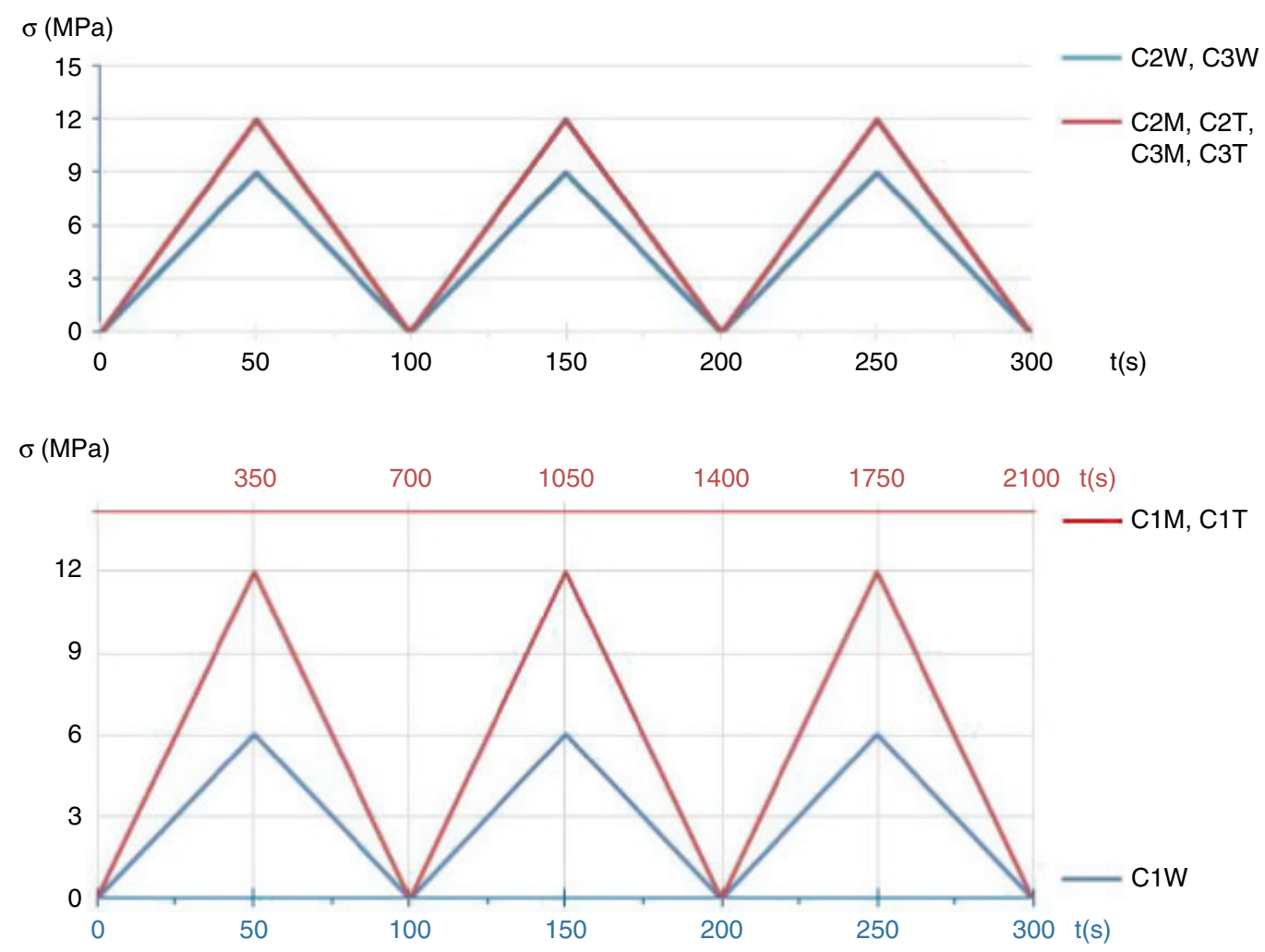

FIGURE 2. Loading cycles applied to all specimens.

by means of an MTS 632.11F.20 extensometer. Results were represented as longitudinal and transversal stress-strain curves. Longitudinal elastic modulus and Poisson's ratio values were calculated. Specimens were subsequently subjected to compressive strength testing up to fracture, in accordance with EN 12390-2 (35), so as to obtain the ultimate strength values.

\section{RESULTS}

Table 3 shows results for the three loading cycles and compressive testing up to fracture.

The first six columns show elastic modulus (E) and Poisson's ratio (v) values for each loading cycle. The values are those obtained for a stress equal to $40 \%$ of the estimated ultimate fracture. The seventh column shows values for ultimate failure stress $\left(\sigma_{\mathrm{r}}\right)$ and the last three columns show mean elastic modulus, Poisson's ratio and ultimate strength values for each set of specimens and the specimen conditions on testing. The elastic modulus and Poisson's ratio values were obtained from the third loading cycle data (41). It should be noted that the standard refers to concrete specimens, not to FRP-confined concrete specimens.

Specimens failed (Figure 3) when the CFRP fractured perpendicularly to the fibre. No noticeable visual differences were evident for the two reinforcement levels $(50 \%$ and $100 \%)$ or the three specimen types $(\mathrm{C} 1, \mathrm{C} 2$ and $\mathrm{C} 3)$. Fracturing was preceded by sounds that indicated initial fracturing of the fibres. Satisfactory concrete-CFRP bonding was in all cases indicated by the attachment of a thin layer of concrete to the fibre. Fracturing occurred in areas of overlap between fibres.

\section{ANALYSIS AND DISCUSSION}

\subsection{Loading cycles: $\mathrm{C} 1$ behaviour}

Figures 4, 5 and 6 show the first, second and third loading cycle results, respectively, for $\mathrm{C} 1 \mathrm{com}$ pressive tests for non-reinforced specimens and 50\% and $100 \%$ CFRP-reinforced specimens. The figures show the evolution of longitudinal strain (right) and transversal strain (left). The y-axis (the same for all the figures) indicates the stress level.

In the first loading cycle (Figure 4), the nonreinforced specimens reached stress close to $65 \%$ of the ultimate fracture. Behaviour was almost linear up to approximately $2 \mathrm{MPa}$, from which point the concrete lost rigidity almost directly in line with the stress level, as can be seen from the linear behaviour of the elastic modulus. In subsequent loading cycles (Figures 5 and 6), the rigidity of the non-reinforced specimens remained constant, as confirmed by the linearity of the longitudinal stress-strain curves and by elastic modulus non-dependence on the stress 
TABLE 3. Compression test results for the three loading cycles

\begin{tabular}{|c|c|c|c|c|c|c|c|c|c|c|}
\hline & \multicolumn{6}{|c|}{ LOADING CYCLES } & \multirow{3}{*}{$\begin{array}{c}\text { FAILURE } \\
\text { STRESS } \\
\sigma_{\mathrm{r}} \\
\left(\mathrm{N} / \mathbf{m m}^{2}\right) \\
\end{array}$} & \multirow{2}{*}{\multicolumn{3}{|c|}{ MEAN VALUES }} \\
\hline & \multicolumn{2}{|c|}{ CYCLE 1} & \multicolumn{2}{|c|}{ CYCLE 2} & \multicolumn{2}{|c|}{ CYCLE 3} & & & & \\
\hline & $\begin{array}{c}E_{1} \\
\left(\mathbf{N} / \mathbf{m m}^{2}\right)\end{array}$ & $v_{1}$ & $\begin{array}{c}\mathbf{E}_{2} \\
\left(\mathbf{N} / \mathrm{mm}^{2}\right)\end{array}$ & $v_{2}$ & $\begin{array}{c}\mathbf{E}_{3} \\
\left(\mathbf{N} / \mathbf{m m}^{2}\right)\end{array}$ & $v_{3}$ & & $\begin{array}{c}\mathbf{E} \\
\left(\mathrm{N} / \mathrm{mm}^{2}\right)\end{array}$ & $v$ & $\begin{array}{c}\sigma_{\mathrm{r}} \\
\left(\mathrm{N} / \mathrm{mm}^{2}\right)\end{array}$ \\
\hline C1W1 & 13004 & 0.14 & 12125 & 0.15 & 11892 & 0.15 & 8.47 & $11<05$ & 015 & 05 \\
\hline C1W2 & 11189 & 0.14 & 11648 & 0.16 & 11472 & 0.16 & 8.48 & 11685 & 0.15 & 8.5 \\
\hline C1M3 & 3387 & 0.19 & 3605 & 0.21 & 3627 & 0.21 & 22.5 & 2124 & 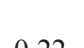 & 22 \\
\hline C1M4 & 3394 & 0.20 & 2756 & 0.21 & 2641 & 0.23 & 22.3 & 3134 & 0.22 & 22.4 \\
\hline C1T5 & 3854 & 0.19 & 3981 & 0.20 & 3668 & 0.20 & 23.2 & & & \\
\hline C1T6 & 3860 & 0.23 & 3670 & 0.22 & 3463 & 0.22 & 22.1 & 3565 & 0.21 & 22.6 \\
\hline $\mathrm{C} 2 \mathrm{~W} 7$ & 21524 & 0.15 & 22424 & 0.15 & 22213 & 0.15 & 22.6 & 21700 & 015 & 215 \\
\hline $\mathrm{C} 2 \mathrm{~W} 8$ & 21026 & 0.15 & 21215 & 0.16 & 21368 & 0.16 & 20.4 & 21790 & 0.15 & 21.5 \\
\hline С2M9 & 15577 & 0.15 & 15811 & 0.17 & 15203 & 0.18 & 34.7 & $1660 ?$ & 016 & 320 \\
\hline $\mathrm{C} 2 \mathrm{M} 10$ & 17475 & 0.14 & 18454 & 0.15 & 18182 & 0.15 & 31.2 & 10092 & 0.10 & 32.9 \\
\hline $\mathrm{C} 2 \mathrm{~T} 11$ & 16416 & 0.15 & 17642 & 0.18 & 16341 & 0.17 & 35.5 & 15234 & 016 & 227 \\
\hline $\mathrm{C} 2 \mathrm{~T} 12$ & 14219 & 0.15 & 14909 & 0.15 & 14238 & 0.15 & 31.9 & 15334 & 0.10 & 35.1 \\
\hline $\mathrm{C} 3 \mathrm{~W} 13$ & 26566 & 0.15 & 28699 & 0.17 & 28910 & 0.17 & 26.2 & & & \\
\hline C3W14 & 24171 & 0.15 & 25924 & 0.16 & 25420 & 0.16 & 25.2 & 27165 & 0.16 & 25.7 \\
\hline C3M15 & 25685 & 0.15 & 25990 & 0.15 & 25990 & 0.15 & 41.8 & 22420 & 016 & 126 \\
\hline C3M16 & 24171 & 0.14 & 25924 & 0.16 & 25421 & 0.16 & 45.5 & 23428 & 0.10 & 43.6 \\
\hline C3T17 & 20268 & 0.15 & 21137 & 0.16 & 21434 & 0.16 & 49.3 & 20541 & 016 & 480 \\
\hline C3T18 & 23726 & 0.15 & 23752 & 0.15 & 23649 & 0.15 & 48.6 & 22541 & 0.10 & 48.9 \\
\hline
\end{tabular}
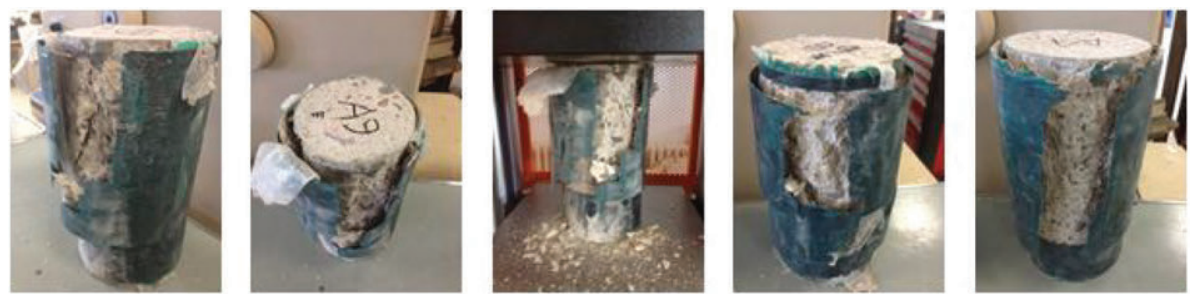

Figure 3. Confined concrete specimens tested to compression up to fracture.

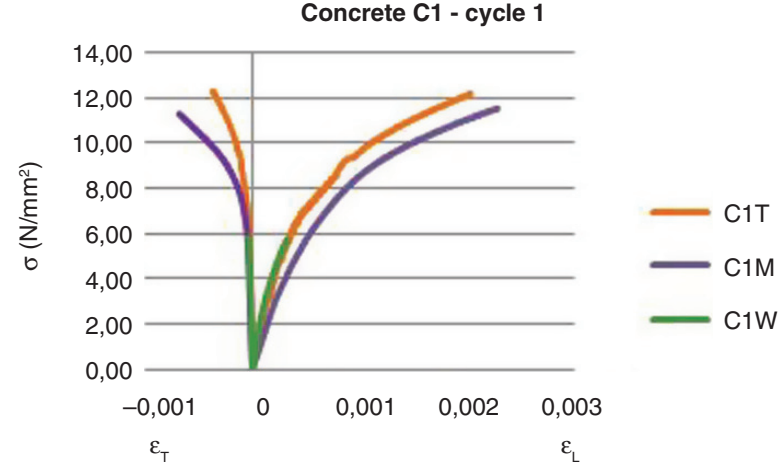

FIGURE 4. First loading cycle. Results for C1.

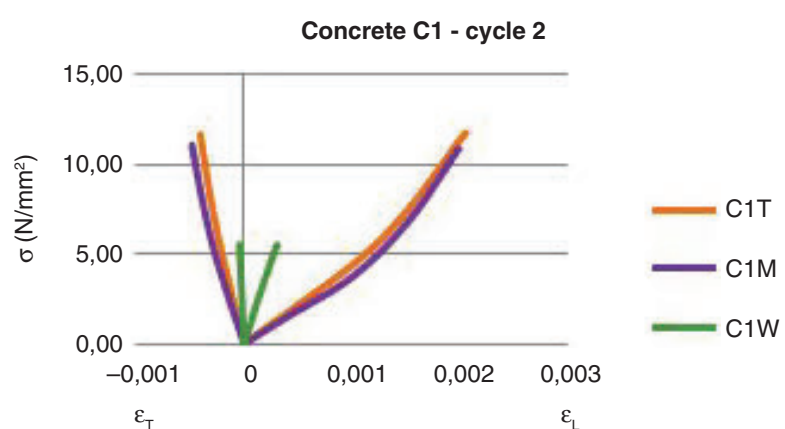

FIGURE 5. Second loading cycle. Results for C1. 


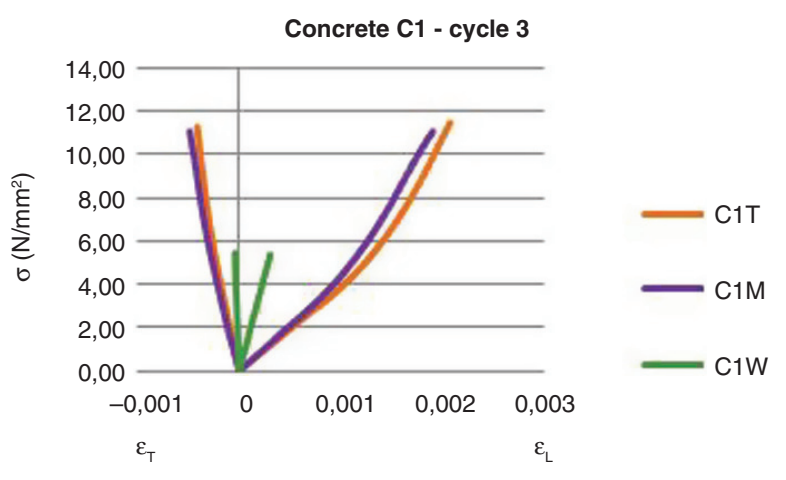

FIGURE 6. Third loading cycle. Results for C1.

level. On attainment of maximum stress in the first loading cycle, the concrete maintained internal micro-fusion stability; consequently, in the second loading cycle, elastic modulus evolution in line with stress commenced at a value that was greater than that resulting at the end of the first loading cycle.

As for the $50 \%$ and $100 \%$ CFRP-reinforced C1 specimens, in the first loading cycle these underwent stress to close to $12 \mathrm{MPA}$, thereby exceeding ultimate concrete fracturing without confinement; as a result, the inner concrete was completely cracked. Longitudinal stress-strain for the reinforced specimens was slightly more rigid than that for the non-reinforced concrete (see Figure 4). More rigidity was evident in the $100 \%$ compared to the $50 \%$ CFRP-reinforced specimens. As a result of the stress and the deterioration in the concrete after the first loading cycle, the reinforced specimens lost a fraction of their rigidity by the end of the first loading cycle (see Figure 4).

Subsequent loading cycles show that the longitudinal stress-strain performance of the reinforced specimens became slightly more rigid as the stress level increased. This is because the completely cracked concrete could not contribute to the rigidity of the tested specimen; hence, the specimen was only affected by the rigidity of the CFRP. The elastic modulus values decreased sharply relative to those for the first loading cycle; in contrast, they increased slightly with the stress level (Figure 5).

\subsection{Loading cycles: $\mathrm{C} 2$ and $\mathrm{C} 3$ behaviour}

Behaviour was very similar for the $\mathrm{C} 2$ and $\mathrm{C} 3$ specimens. Figures 7 and $8-$ which can be interpreted analogously to Figures 4 and 6, respectively show behaviour for the first and third loading cycles, respectively. Since the results for the second loading cycle virtually coincide with those for the third loading cycle, no further figures are included here.

Stress attained in the first loading cycle for $\mathrm{C} 2$ and $\mathrm{C} 3$ did not reach $75 \%$ of the ultimate fracture so unstable cracking did not occur. There was, consequently, significant degradation in the concrete, as

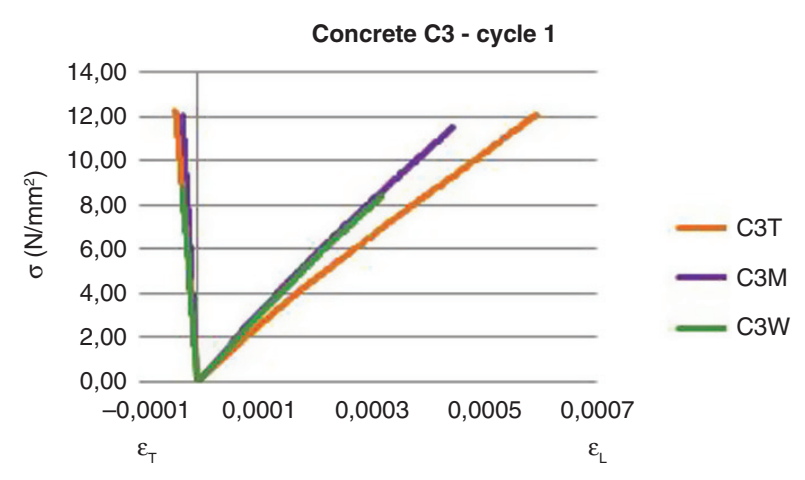

Figure 7. First loading cycle. Results for C3.

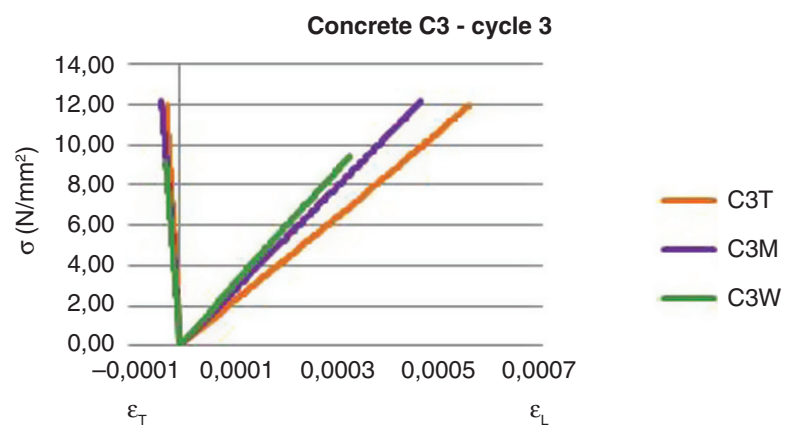

FIgURE 8. Third loading cycle. Results for C3.

happened with the CFRP-reinforced $\mathrm{C} 1$ specimens. For the reinforced specimens during the second and third loading cycles, elastic modulus values did not drop significantly from the values obtained in the first loading cycle. Behaviour of the three specimens was very similar in the three loading cycles.

\subsection{Loading cycles: rigidity comparisons}

Figure 9 shows mean elastic modulus values for each set of unconfined and confined specimens.

These values were obtained for a stress level representing $40 \%$ of the ultimate strength estimated for each specimen, coinciding approximately with the service strength value. Service strength was significantly higher for the reinforced specimens compared to the non-reinforced specimens. At the 40\% stress value, concrete was already microcracked internally and, consequently, the elastic modulus for the reinforced specimens (obtained for the service strength value) was smaller than for the nonreinforced specimens. Likewise, the elastic modulus was also smaller for the reinforced specimens in the third loading cycle. In service conditions, therefore, the rigidity of the reinforced structure would be less than in the original (non-reinforced) structure. For the $\mathrm{C} 2$ and $\mathrm{C} 3$ specimens, the elastic modulus values were $30 \%$ and $17 \%$ lower for the $100 \%$ CFRPreinforced specimens than for the non-reinforced 


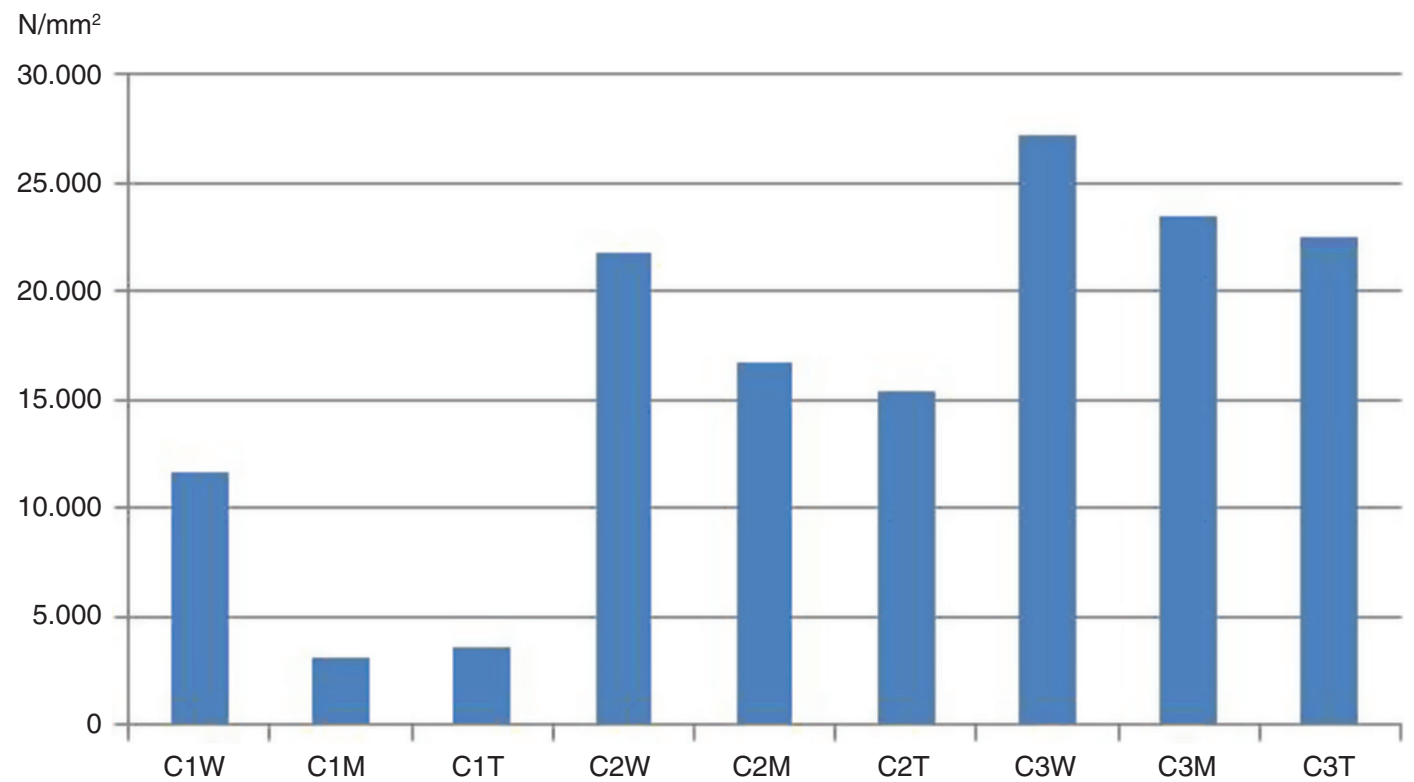

FIGURE 9. Mean elastic modulus values.

TABLE 4. Mean ultimate strength values for all 18 tested specimens

\begin{tabular}{lccccccccc}
\hline & C1W & C1M & C1T & C2W & C2M & C2T & C3W & C3M & C3T \\
\hline$\sigma_{\mathrm{r}}(\mathrm{MPa})$ & 8.5 & 22.4 & 22.7 & 21.5 & 32.9 & 33.7 & 25.7 & 43.6 & 49.0 \\
\hline
\end{tabular}

TABLE 5. Estimated and experimental ultimate strength values for confined concrete

\begin{tabular}{lcccc}
\hline Specimen type & $\mathbf{f}_{\mathbf{c}}(\mathbf{M P a})$ & $\mathbf{f}_{\mathrm{cc}, \mathrm{c}}(\mathbf{M P a})$ & $\mathbf{f}_{\mathrm{cc,e}}(\mathbf{M P a})$ & $\mathbf{f}_{\mathrm{cc}, \mathrm{e}} / \mathbf{f}_{\mathrm{ccc,c}}$ \\
\hline $\mathrm{C} 1$ & 8.5 & 17.5 & 22.7 & 1.3 \\
$\mathrm{C} 2$ & 20.4 & 29.4 & 33.7 & 1.1 \\
$\mathrm{C} 3$ & 25.2 & 34.2 & 49 & 1.4 \\
\hline
\end{tabular}

specimens; the decrease was $70 \%$ for the $\mathrm{C} 1$ specimens with unstable cracking in the reinforced specimens, Rigidity loss values as obtained during the cyclic testing were consistent with those reported by other authors (32-33).

\subsection{Reinforced specimens: ultimate fracture strength}

Table 4 shows the mean values for the nonreinforced specimens $(\mathrm{C} 1 \mathrm{~W}, \mathrm{C} 2 \mathrm{~W}$ and $\mathrm{C} 3 \mathrm{~W})$ and the $50 \%(\mathrm{C} 1 \mathrm{M}, \mathrm{C} 2 \mathrm{M}$ and $\mathrm{C} 3 \mathrm{M})$ and $100 \%(\mathrm{C} 1 \mathrm{~T}$, C2T and C3T) CFRP-reinforced specimens.

Strength increased more in the confined concrete than in the low-strength concretes, corroborating results reported by other authors (26-27). For the $100 \%$ CFRP-reinforced specimens, the ultimate strength values increased by 2.67 for the $\mathrm{C} 1$ specimens and by 1.57 and 1.9 for the $\mathrm{C} 2$ and $\mathrm{C} 3$ specimens, respectively.

In addition, differences between ultimate strength values for the $50 \%$ CFRP-reinforced specimens and the 100\% CFRP-reinforced specimens were very small, at $99 \%, 98 \%$ and $89 \%$ for $\mathrm{C} 1, \mathrm{C} 2$ and $\mathrm{C} 3$, respectively. This would indicate that the ultimate fracture strength of confined elements would be quite unaffected by implementation defects, since, even in the extreme $50 \%$ test conditions, the maximum strength decrease was $11 \%$ with respect to the non-defective specimens.

Table 5 shows, for each specimen type, the experimentally obtained ultimate strength values $\left(f_{c}\right)$, the ACI (3) confined concrete values $\left(f_{c c, c}\right)$ and the experimentally obtained confined concrete values $\left(\mathrm{f}_{\mathrm{cc}, \mathrm{e}}\right)$, and, in the last column, the ratio between the estimated and experimental confined concrete values.

It can be observed that the ACI estimate was conservative in each case, resulting in estimated values that were lower than those obtained experimentally. Note also that no relationship could be deduced regarding unconfined concrete strength and the deviations between the estimated and experimental values. 


\section{CONCLUSIONS}

In the first loading cycle-with stress values higher than service stress values - the behaviour of confined and unconfined specimens was very similar, except for a slight increase in rigidity in the former. No significant differences in behaviour were observed in the second and the third loading cycles.

When an unstable concrete microcrack level was reached in the first loading cycle (as happened with $\mathrm{C} 1$ ), rigidity sharply decreased in subsequent cycles. When stress increased, rigidity also increased slightly; likewise, the elastic modulus value also increased slightly as stress increased.

The percentage strength increase due to confinement was far higher in the low-resistance concrete than in the medium-resistance concretes.

Reinforcement resulting from concrete confinement was unaffected by defective implementation. Even for fibre tissues bonded to only $50 \%$ of the outer surface, the maximum strength decrease was $11 \%$ relative to the non-defective specimens.

Confined specimen fracturing was due to fracturing of the CFRP. When fracturing occurred, a thin layer of concrete attached to the CFRP, indicating, therefore, good bonding performance between the two materials. Fractures occurred outside CFRP overlap areas.

We suggest that the ACI equation for estimating confined concrete strength is conservative, as no relationship could be deduced regarding unconfined concrete strength and the deviations between estimated and experimental values.

An issue that should be taken into account in evaluating reinforced structures is that the reinforced specimens were less rigid than the non-reinforced specimens for stress values representing $40 \%$ of the concrete ultimate strength value.

\section{REFERENCES}

1. Maaddaway, T. (2009) Strengthening of eccentrically loaded reinforced concrete columns with fiber-reinforced polymer wrapping system: experimental investigation and analytical modelling. J. Compos. Constr. 13 [1], 13-24. http://dx.doi. org/10.1061/(ASCE)1090-0268(2009)13:1(13).

2. Machida, A. (Ed) (1993) State of the art report on continuous fiber reinforcing materials. Second Research Committee on CFRM, Japan Society of Civil Engineers: Concrete Engineering Series 3. Tokyo

3. American Concrete Institute (2008) ACI 440.2R-08. Guide for the design and construction of externally bonded FRP systems for strengthening concrete structures. Detroit, Mich.: American Concrete Institute.

4. Neale, K.W.; Labousièrre, P. (1992) Advanced composites materials in bridges and structures. Proc. $1^{\text {st }}$ Int. Conf. On Advanced Composites Materials in Bridges and Structures, CSCE, Sherbrocke, Quebec, Canada.

5. Nanni, A.; Di Tomaso, A.; Arduini, M. (1996) International research on advanced composites in construction, National Science Foundation, Arlington, Va, Final report No. IRACC-96.

6. Saadatmanesh, H.; Ehsani, M.R.; Li, M.W. (1994) Strength and ductility of concrete columns externally reinforced with fiber composite straps. ACI Structural J. 91 [4], 434-447.
7. Elsanadedy, H.M.; Al-Salloum, Y.A.; Abbas, H.; Alsayed, S.H. (2012) Prediction of strength parameters of FRPconfined concrete. Comp. Part B: Eng. 43 [2], 228-239. http://dx.doi.org/10.1016/j.compositesb.2011.08.043.

8. International Federation for Structural Concrete (CEBFIB), (2001) Externally bonded FRP reinforcement for RC structures. fib Bulletin 14, Laussanne, Switzerland.

9. Japan Society of Civil Engineers. (2001) Recommendations for upgrading of concrete structures with use of continuos fiber sheets. In: Maruyama K. (Ed). Concrete Engineering Series 41: March 2001.

10. CNR-DT 200/2004 (2004) Guide for the design and construction of externally bonded FRP systems for strengthening existing structures, Advisory Committee on Technical Recommendations for Construction, National Research Council, Rome, Italy.

11. Toutanji, H. (1999) Stress-strain characteristics of concrete columns externally confined with advanced fiber composites sheets. ACI Mat. Journal. 96 [3], 397-404. http://dx.doi. org/10.14359/639.

12. Nanni, A.; Norris, M.S.; Bradford, N.M. (1993) Lateral confinement of concrete using FRP reinforcement, In Proc., International Symposium on FRP Reinforcement, Vancouver, Canada, ACI SP-138 American Concrete Institute, March 30-31 1993, 193-209.

13. Larralde, J. (1997) Compressive strength of small concrete specimens confined with fibreglass laminates. Cem. Concr. Aggreg 19 [1], 17-21. http://dx.doi.org/10.1520/CCA10016J.

14. Saafi, M.; Toutanji, H.; Li, Z. (1999) Behaviour of concrete columns confined with fiber reinforced polymer tubes. ACI Mat. Journal. 96 [4], 500-509. http://dx.doi. org/10.14359/652

15. Csuka, B.; Kollár, L.P. (2010) FRP confined circular concrete columns subjected to concentric loading. Reinf. Plast. Compos. 29 [23], 3504-3520. http://dx.doi. org/10.1177/0731684410381448.

16. Aire, C.; Gettu, R.; Casas, J.R.; Marques, S.; Marques, D. (2010) Concrete laterally confined with fibre-reinforced polymers (FRP): Experimental study and theoretical model. Mater. Construcc. 60 [297], 19-31. http://dx.doi. org $/ 10.3989 / \mathrm{mc} .2010 .45608$

17. de Diego, A., Arteaga, A., Fernández, J., Perera, R., \& Cisneros, D. (2015) Behaviour of FRP confined concrete in square columns. Mater. Construcc, 65(320): e069. http:// dx.doi.org/10.3989/mc.2015.05414

18. Csuka, B.; Kollár, L.P. (2012) Analysis of FRP confined circular columns under eccentric loading. Compos. Struct. 94 [3], 1106-1116. http://dx.doi.org/10.1016/j.compstruct. 2011.10.012.

19. Daugevičius, M.; Valivonis, J.; Beinaravičius, A.; Skuturna, T.; Budvytis, M. (2013) Experimental investigation of the load carrying capacity of eccentrically loaded reinforced concrete elements strengthened with CFRP. Proc. Eng. 57, 232-237. http://dx.doi.org/10.1016/j.proeng.2013.04.032

20. Harmon, T.G.; Ramakrishran, S.; Wang, E.H. (1998) Confined concrete subjected to uniaxial monotonic loading. J. Eng. Mechan. 124 [12], 1303-1309. http://dx.doi. org/10.1061/(ASCE)0733-9399(1998)124:12(1303).

21. Li, Q.; Ansari, F. (2000) High-strength concrete in triaxial compression by different size of specimens. ACI Materials Journal. 97 [6], 684-689. http://dx.doi.org/10.14359/9982.

22. Setunge, S.; Attard, M.M.; Darvall, P.L. (1993) Ultimate strength of confined very high-strength concretes. ACI Structural Journal. 90 [6], 632-641.

23. Xie, J.; Elwi, A.E.; MacGregor, J.G. (1995) Mechanical properties of three high-strength concretes containing silica fume. ACI Mat. Journal. 92 [2], 135-145. http://dx.doi. org/10.14359/9764.

24. Aire, C. (2002) Estudio experimental del comportamiento del hormigón confinado sometido a compresión. PhD Thesis. Universitat Politècnica de Catalunya, Spain.

25. Almusallam, T.H. (2007) Behaviour of normal and highstrength concrete cylinders confined with E-glass/epoxi composite laminates. Comp. Part B: Eng. 38 [5-6], 629-639. http://dx.doi.org/10.1016/j.compositesb.2006.06.021. 
26. Micelli, F.; Modarelli, R. (2013) Experimental and analytical study on properties affecting the behaviour of FRPconfined concrete. Comp. Part B: Eng. 45 [1], 1420-1431. http://dx.doi.org/10.1016/j.compositesb.2012.09.055.

27. Vincent, T.; Ozbakkaloglu, T. (2013) Influence of concrete strength and confinement method on axial compressive behavior of FRP confined high and ultra high-strength concrete. Comp. Part B: Eng. 50, 413-428. http://dx.doi. org/10.1016/j.compositesb.2013.02.017.

28. Lam, L.; Teng, J.G. (2009) Stress-strain model for FRPconfined concrete under cyclic axial compression. Eng. Struct. 31, 308-321. http://dx.doi.org/10.1016/j.engstruct. 2008.08.014.

29. Abbsania, R.; Ziaadiny, H. (2010) Behavior of concrete prisms confined with FRP composites under axial cyclic compression. Eng. Struct. 32(3), 648-655. http://dx.doi. org/10.1016/j.engstruct.2009.11.011.

30. Abbsania, R.; Hosseinpour, F.; Rostamian, M.; Ziaadiny, H. (2013) Cyclic and monotonic behavior of FRP confined concrete rectangular prisms with different aspect radios. Construc. Build. Mat. 40, 118-125. http://dx.doi. org/10.1016/j.conbuildmat.2012.10.008

31. Faustino, P.; Frade, P.; Chastre, C. (2016) Lateral cyclic behaviour of RC columns confined with carbon fibres. Structures 5, 196-206. http://dx.doi.org/10.1016/j.istruc.2015.11.004.

32. Bouchelaghem, H.; Bezazi, A.; Scarpa, F. (2011) Compressive behaviour of concrete cylindrical FRPconfined columns subjected to a new sequential loading technique. Comp. Part B:42(7), 1987-1993. http://dx.doi. org/10.1016/j.compositesb.2011.05.045.
33. Li, P.; Wu, Y.-F. (2015) Stress-strain model of FRP confined concrete under cyclic loading. Composite Structures 134, 60-71. http://dx.doi.org/10.1016/j.compstruct.2015. 08.056 .

34. Mehta, P.K.; Monteiro, P.J.M. (2006) Concrete, Microstructure, Properties and Materials. Third Edition. The McGraw-Hill Companies Inc. New York, (2006).

35. EN 12390-2:2009. Testing hardened concrete - Part 2: Making and curing specimens for strength tests.

36. Lam, L.; Teng, J. (2003) Design-oriented stress-strain model for FRP-confined concrete. Construc. Build. Mat. 17 [6-7], 471-489. http://dx.doi.org/10.1016/S0950-0618(03)00045-X

37. Lam, L.; Teng. J. (2003) Design-oriented stress-strain model for FRP-confined concrete in rectangular columns. J. Reinf. Plastics \& Comp. 22 [13], 1149-1186. http://dx.doi. org/10.1177/0731684403035429.

38. Pessiki, S.; Harries, K.A.; Kestner, J.; Sause, R.; Ricles, J.M. (2001) The axial behaviour of concrete confined with fiber reinforced composite jackets. J. Compos. Constr. 5 [4], 237-245. http://dx.doi.org/10.1061/(ASCE)1090-0268(2001)5:4(237)

39. Harries, K.A.; Carey, S.A. (2003) Shape and "gap" effects on the behaviour of variably confined concrete. Cem. Concr. Res. 33 [6], 881-890. http://dx.doi.org/10.1016/ S0008-8846(02)01085-2.

40. Carey, S.A.; Harries, K.A. (2005) Axial behaviour and modeling of confined small-, medium-, and large-scale circular sections with CFRP jackets. ACI Structural Journal. American Concrete Institute. 102 [4], 596-604.

41. EN 12390-3:2009. Testing hardened concrete - Part 3: Compressive strength of test specimens. 